Article

\title{
How Do Corporate Social Responsibility and Corporate Governance Affect Stock Price Crash Risk?
}

\author{
Ahmed Imran Hunjra ${ }^{1, *(D)}$, Rashid Mehmood ${ }^{1}$ and Tahar Tayachi ${ }^{2} \mathbb{D}$ \\ 1 University Institute of Management Sciences, PMAS-Arid Agriculture University Rawalpindi, \\ Rawalpindi 46000, Pakistan; rashidm1005@gmail.com \\ 2 Finance Department, Effat University, Jedda 21478, Saudi Arabia; ttayachi@effatuniversity.edu.sa \\ * Correspondence: ahmedhunjra@gmail.com
}

Received: 20 December 2019; Accepted: 4 February 2020; Published: 7 February 2020

\begin{abstract}
We investigate the impact of corporate social responsibility (CSR) and corporate governance on stock price crash risk in manufacturing sector of India and Pakistan. We collect data of nine years from 2010 to 2018 from DataStream of 353 manufacturing firms. We apply the Generalized Method of Moments (GMM) to the analysis of the data. We find that when firms actively engage in CSR activities, they lead to reduced stock price crash risk. We further find that managerial ownership has a significant positive impact on stock price crash risk, while board size and CEO duality show a significant and negative impact on stock price crash risk.
\end{abstract}

Keywords: CSR; corporate governance; stock price crash risk; manufacturing sector; GMM

\section{Introduction}

Corporate social responsibility (CSR) demands firms to engage in contributing towards improvements in the environment and society. CSR is the concern of firms toward customers, environment and societies while generating profits and keeping the responsibility of fulfilling the requirements of employees and owners. The incorporation of CSR practices into a firm's business activities and decision making leads to competitiveness, provides business opportunities in new markets, and ultimately helps to ensure firms' sustainability. Therefore, firms focus on enhancing economic value, fulfilling their responsibilities, and contributing to society through an effective governance system. Firms with more social responsibilities enjoy moral prospects of society by showing better social behavior. However, how CSR practices increase or decrease the wealth of shareholders, enhance transparency about information, help to reduce the volatility of stock prices, and protect the interests of investors. These issues need to be addressed. In a competitive business environment, CSR has gained strategic importance. Firms with more social responsibility lead to higher transparency in financial reporting standards and ethical standards (Lee 2016).

Firms with social responsibility reveal more financial outcomes and are involved less in earnings management and bad news (Schuler and Cording 2006; Kim et al. 2012). CSR practices decrease stock price crash risk (Kim et al. 2014). Crash risk involves asymmetry in risks, which is mainly downside risk, and it is important to make decisions relating to risk management and investment. Along with financial outcomes, stakeholders are also concerned with the social outcomes of the firms (Darus et al. 2014). For proper implementation of CSR practices, firms need to incorporate an effective governance system. A good corporate governance system helps firms to achieve their financial outcomes. The concept of corporate governance is of immense importance as it includes the relationship between the management of a firm, board of directors, shareholders and stakeholders (Bhasin and Shaikh 2013). (Claessens and Yurtoglu 2013) note that an efficient governance system is helpful for firms through improved financial performance, better access to finance, and more desirable 
handling of stakeholders. Good practices in corporate governance line up managers' and shareholders' interests. (Mitton 2002; Lemmon and Lins 2003) conclude that during recessions, stock prices drop more for the firms with weak corporate governance due to the personal benefits of executives. Weak internal control leads towards bad news hoarding in the market, which can adversely affect the stock prices, ultimately minimizing profits. Stock prices of the firms with weak corporate governance structure have a tendency to drop more in the contracting economy.

The focus of this study is the emerging economies (Pakistan \& India) of South Asia because CSR practices are not up to standards in this region. This region lacks the application of good corporate governance. More socially-responsible firms employ codes of good corporate governance that mitigate the crash risk. There is growing trend of literature available regarding CSR and financial performance of the firms (for example, (Roman et al. 1999; Jiao 2010; Callan and Thomas 2014)), and CSR practices and their impact on capital cost (El Ghoul et al. 2011; Dhaliwal et al. 2011; Goss and Roberts 2011). Past studies explain the concept of CSR, but they still are lacking with respect to the governance system and the way these components affect the crash risk of stock prices, mainly in emerging economies. Furthermore, while explaining the concept of CSR, it is necessary to include corporate governance with major decision-makers such as directors in the board, CEOs, and ownership structures. These decision-makers have the authority to control the activities of the firms, as well as provide guidelines for policymaking. Boards of directors are becoming more aware of CSR practices (Boubaker and Nguyen 2012). The application of corporate governance practices is comparatively not very effective in emerging countries like Pakistan and India (Hunjra et al. 2020). Emerging economies and firms are facing the issue of corporate governance and trying to find out ways to improve the governance system in order to compete effectively and attract investors (Boubaker and Nguyen 2014). In addition, there is a lack of CSR education in the context of developing economies (Ali and Frynas 2018). Firms in developing countries such as Pakistan and India face the issues of paying taxes, work-related health and safety, environmental protection, employees' training, and human rights. Therefore, there is a need to analyze CSR practices in the developing economy context. Moreover, (Claessens and Yurtoglu 2013) describe that for a firm, effective corporate governance is helpful through access to funds and the required treatment of firms' stakeholders.

Therefore, we aim to analyze how CSR practices and corporate governance affect stock price crash risk in developing economies like Pakistan and India. The objective of our study is to determine the impact of CSR and corporate governance on stock price crash risk. We analyze the data of 353 manufacturing firms from Pakistan and India and apply GMM for hypothesis testing. The results of our study indicate that CSR and corporate governance of firms help to decrease stock price crash risk, which protects shareholders' interests. Our study helps to promote CSR activities, improve corporate governance practices, and stabilize the capital market. Findings of our study are relevant to the concept that when firms actively operate in CSR activities, they refrain from bad news hoarding, which results in decreasing stock price crash risk.

The remaining portion of the research is organized as follows: We present literature in Section 2; data and methodology in Section 3. Section 4 describes the empirical outputs, whereas Section 5 concludes the study with insights for future work.

\section{Review of Literature}

The crash risk is linked with the negative skewness for the distribution of returns of individual stocks (Callen and Fang 2015; Chen et al. 2001; Kim et al. 2014). Furthermore, crash risk takes into account stock movements which are on the higher side, like extreme negative movements. Investors hope to earn higher returns on stocks which have more negative skewness in consideration to the fact that skewness is a priced risk factor (Conrad et al. 2013; Harvey and Siddique 2000). Jin and Myers (2006) state that stock crash risks are linked to the presence of information asymmetries due to the fact that managers or insiders have more control and can hide information from external shareholders. 
The concept of CSR gained popularity in the 1960s era, when firms showed responsibility towards society at large as one of its stakeholders. Since then, the focus has been growing around the globe. Mallouh and Tahtamouni (2018) describe CSR as involving social acts such as protecting environmental safety, protection against pollution, and providing job opportunities to the local community. Theoretically, CSR is a significant aspect influencing the value of information disclosure of firms and crash risk (Dai et al. 2019). CSR mainly relates to maximizing the social welfare and sustainability of firms with active management to ensure responsibilities for their stakeholders (Clarkson 1995). Businesses have changed their structures and feature departments for managing their social obligations more effectively and to ensure that their efforts are focused in the right direction while engaging with the larger society and local communities. Gelb and Strawser (2001) document that firms undertaking socially-responsible activities are relatively more transparent in providing reliable financial disclosure. It is relevant to the view that firms judge an increase in disclosure of financial information as a way of responsible behavior towards society in the general application of CSR activities. Such firms are more likely to show high transparency and rarely hide bad news from owners. Therefore, we can say that such firms are less prone to crash risks. Through engaging in CSR practices, firms can motivate consumers and investors, helping firms overcome financial issues (Hillman and Keim 2001; Choi and Wang 2009).

Kim et al. (2014) reveal a lower crash risk for such firms that are more transparent with their CSR disclosures. Unfortunately, some managers misuse such disclosures for better impression management to cover poor performance rather than to actually reporting the firm's true efforts under CSR. Lee (2016) uses a sample of the Taiwan stock exchange and finds that CSR shows that the more responsible firms are less exposed to crash risks. Zhang et al. (2016) examine the impact of philanthropic action on crash risk in China and conclude that it shows the same relationship. It, therefore, leaves a gap to discover the channels through which the CSR could mitigate the factors of hiding bad news and crash risk. For instance, firms that are more engaged in CSR are likely to decrease their crash risk (Kim et al. 2011a). However, Hao et al. (2018) conduct a study while taking a sample of Chinese firms and conclude an inverse impact of CSR on crash risk. Dai et al. (2019) find a non-linear association between CSR practices of listed firms operating in China and their stock price crash risk.

Hypothesis 1 (H1). CSR negatively impacts the stock price crash risk.

Corporate governance helps to protect the interests of firms' owners and other stakeholders. According to (Brennan and Solomon 2008), the process of corporate governance ensures the protection of the interests of firms' stakeholders by supervising the management's activities. According to stewardship theory of (Donaldson 1990; Donaldson and Davis 1991), and resource dependence theory of (Pfeffer 1972; Pfeffer and Salancik 1978), when CEOs also have a dual role as chairman of the board, they act for the interests of owners with integrated and strong leadership. Corporate governance practices help to prevent resourceful behaviors of management and decrease crash risk (Shleifer and Vishny 1997; An and Zhang 2013). The decrease in stock price crash risk ultimately helps to improve the financial outcomes of firms. Rossi et al. (2015) highlight a general concept that corporate governance practices influence the firm's performance and enhance owners' protections; therefore, it increases worldwide attention. An effective governance system also improves the accounting information quality and value of a firm (Bhagat and Bolton 2008; Alkurdi et al. 2019). Jensen and Meckling (1976) develop agency theory explaining that managers act for their personal benefits rather than shareholders' benefits which lead to inefficient utilization of resources. Ayadi and Boujelbène (2015) justify that small board size enhances communication and coordination among members of boards, ensures better internal control and helps to reduce agency conflicts between owners and management. Managerial ownership helps to relate incentives of management to those of owners (Boubaker et al. 2012). Corporate governance plays a crucial part in the disclosure of financial reporting and quality (Larcker et al. 2007; Bedard and Johnstone 2004). It has an impact on the effective 
management of managerial remuneration. Andreou et al. (2016) conclude that a higher number or the equal number of independent and non-executive directors on the audit committee, possessing strong technical expertise and good industrial knowledge, and a well-described governance policy reduces the exposure to crash risk. Earlier research in China on stock price crash risk examines the causes of crash risk, including excessive benefits in state-owned enterprises. Xu et al. (2013) find that such high-value benefits motivate managers to hold bad news for long periods, which can result in higher crash risk.

The level of internal control quality in a firm determines the level to which the above-discussed processes can effectively manage or reduce the crash risk. Firms which have ineffective internal control procedures over their financial reporting mechanism are likely to disseminate less reliable financial information, which becomes a primary cause of crash risk. Chang et al. (2017) conclude that better quality of internal control mechanisms decreases the stock price crash risk. The earning quality reduces the crash risk, and this can be better achieved through dedicated institutional holding which ensures better control and monitoring, ultimately reducing the crash risk (An and Zhang 2013). Callen and Fang (2013) document an inverse association between crash risk and institutional investor's stability in effective monitoring. Boubaker et al. (2014) conclude a direct relation between stock price crash and excessive control while examining French listed firms. This complements their finding of undermining the interest of minority shareholders.

Hypothesis 2 (H2). Corporate Governance negatively impacts the stock price crash risk.

We use a set of control variables, i.e., firm size, return on equity, earning per share and stock volatility in our study. (Harvey and Siddique 2000; Chen et al. 2001) show that the size of a firm positively affects stock price crash risk. (Hutton et al. 2009; Kim et al. 2011a, 2011b) explain that an increase in financial performance helps firms to decrease crash risk. As per the outcomes of (Kim et al. 2014), stock volatility positively influences stock price crash risk.

\section{Sample Selection and Methodology}

We use panel data of 353 manufacturing firms from the emerging economies of South Asia (India and Pakistan). We take 197 firms from India and 156 firms from Pakistan. We collect data from DataStream for nine years from 2010 to 2018. We use descriptive statistics to summarize the data. We further use correlation analysis to explain the relationship between explanatory variables and the issue of multicollinearity. We apply the Generalized Method of Moments (GMM) for hypothesis testing. This technique addresses the variation and bias related to endogeneity issues. For this reason, we use two-step dynamic panel regression which is suitable for a short period and long cross-sectional data. (Arellano and Bond 1991; Arellano and Bover 1995) developed this technique. The technique helps to deal with autoregressive properties of the dependent variable and to handle the issue of endogeneity prevailing in dependent variables along with unabsorbed firm-specific characteristics (González 2013).

We use stock price crash risk as the dependent variable, while we use CSR and corporate governance as independent variables. However, we use a set of control variables in our study, which include firm size, earning management, stock volatility, return on equity and earning per share. We use two proxies for firm-specific crash risk; one is negative conditional skewness (NCSKEW) and the other is down to up volatility (DUVOL). (Chen et al. 2001; Kim et al. 2011b, 2014) also apply the same measures for stock price crash risk. For firm-specific weekly returns, we apply the following model.

$$
r_{i, \tau}=\alpha_{i}+\gamma_{1, i} r_{m, \tau-2}+\gamma_{2, i} r_{m, \tau-1}+\gamma_{3, i} r_{m, \tau}+\gamma_{4, i} r_{m, \tau+1}+\gamma_{5, i} r_{m, \tau+2}+\epsilon_{i, \tau}
$$

where,

$r_{i, \tau}=$ is the return of firm $i$ in week $\tau$,

$r_{m, \tau}=$ is the return on the value-weighted market return in week $\tau$ 
We measure firm related weekly returns as to be the natural log of one plus the residual return from Equation (1) above:

$$
\mathrm{w}_{\mathrm{i}, \tau}=\ln \left(1+\mathrm{e}_{\mathrm{i}, \tau}\right)
$$

While estimating Equation (1), every firm-year is needed to have data of a specific number of weekly stock returns to improve the thin trading concerns.

The first measure of stock price crash risk is Negative Conditional Skewness (NCSKEW). This calculation confines the asymmetry of distributing returns and also is repeatedly explained in past studies. Negative values for the skewness explain data that are left-skewed, and positive values explain data that are right-skewed. NCSKEW can be calculated by considering the negative of the third moment of firm-specific weekly returns for each year and can be stabilized by taking the standard deviation of firm-specific weekly returns and raising it to the third power. We calculate NCSKEW as follows:

$$
\operatorname{NCSKEW}_{i, t}=-\left[n(n-1)^{3 / 2} \sum w^{3}{ }_{i, \tau}\right] /\left[(n-1)(n-2)\left(\sum w^{2}{ }_{i, \tau}\right)^{3 / 2}\right]
$$

This measure is multiplied with negative 1 , so that a higher value corresponds to higher crash risk. The other measure of stock price crash risk is down-to-up volatility of firm related weekly returns (DUVOL). We calculate DUVOL as the natural log of standard deviation ratio of firm-specific weekly returns of firm $i$ in year $t$, which we calculate when the returns are above and below the annual mean.

$$
\operatorname{DUVOL}_{i, t}=\ln \left[\left(\mathrm{n}_{\mathrm{u}}-1\right) \sum_{\operatorname{Down}}^{2}{ }_{\mathrm{i}, \tau} /\left(\mathrm{n}_{\mathrm{d}}-1\right) \sum_{\mathrm{Up}} \mathrm{w}^{2}{ }_{\mathrm{i}, \tau}\right]
$$

where, $n_{u}$ and $n_{d}$ represent the number of up and down weeks for the firm in year $t$, respectively. A

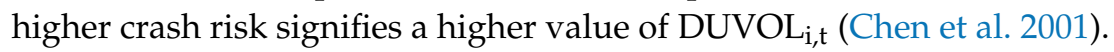

We use two measures of CSR activities; following (Feng et al. 2018; Javeed and Lefen 2019), the first measure includes an index for CSR as social contribution value per share (SCV). This indicator fulfills the environmental, societal and economical aspects of CSR practices of the emerging economies. Further, it helps to understand the social performance of manufacturing firms that how they contribute towards social values. This index incorporates all elements which are necessary for social benefits. These elements include earnings per share, producing value for shareholders, government tax revenue-producing value for society, salaries of employees, interest on loans from creditors, and other values for stakeholders. Furthermore, we eliminate the pollution of the environment as a social cost. We use the following formula to calculate CSV:

$$
\begin{gathered}
\mathrm{CSV}=\text { Earnings per Share }+(\text { Tax Revenue }+ \text { Salaries of Employees }+ \text { Interest on } \\
\text { Loans }+ \text { Public Welfare Expenses }- \text { Social Cost }) / \text { Total Equity }
\end{gathered}
$$

We follow (Camelia-Daniela Hategan et al. 2018) for the second measure of CSR as a binary method of assigning values of 0 and 1 . We place a value 1 if firms have one of four social activities; corporate giving, costs relating to health and safety at workplace (Dumitrescu and Simionescu 2015), expenses relating to training courses of employees (Dumitrescu and Simionescu 2015; Obrad and Gherhes 2018), and expenses connecting with waste management (Istrate et al. 2017), otherwise we use 0. We use three measures of corporate governance which include board size, CEO duality, and ownership structure. These mechanisms of corporate governance represent the main power of decision making of the firms and controlling business activities. We calculate CEO duality as a dummy variable and use 1 when the chairman and CEO in a large firm are the same person, or equal to 0 otherwise. We value board size as the number of members on board. We follow (Mehmood et al. 2019) to measure CEO duality and board size. We follow (Li et al. 2007) to measure managerial ownership as the percentage of shares held by top managers and their families. Following (Widyaningsih et al. 2017), we use the proxy of firm size as a natural log of total assets. We also use return on equity as net income divided by average equity. (Mehmood et al. 2019) apply the same measure of return on equity. We calculate earnings per 
share as net income after interest and tax over a total number of shares issued. (Salim and Yadav 2012) use the same proxy for earning per share. To measure price volatility, we follow the measure of (Habib et al. 2012) and calculate the range of stock prices for each year, and then take an average of the highest and lowest prices. For price volatility, we divide the range by average and then raise the second power. We explain the proxies of variables in Table 1.

Table 1. Variables and their measurements.

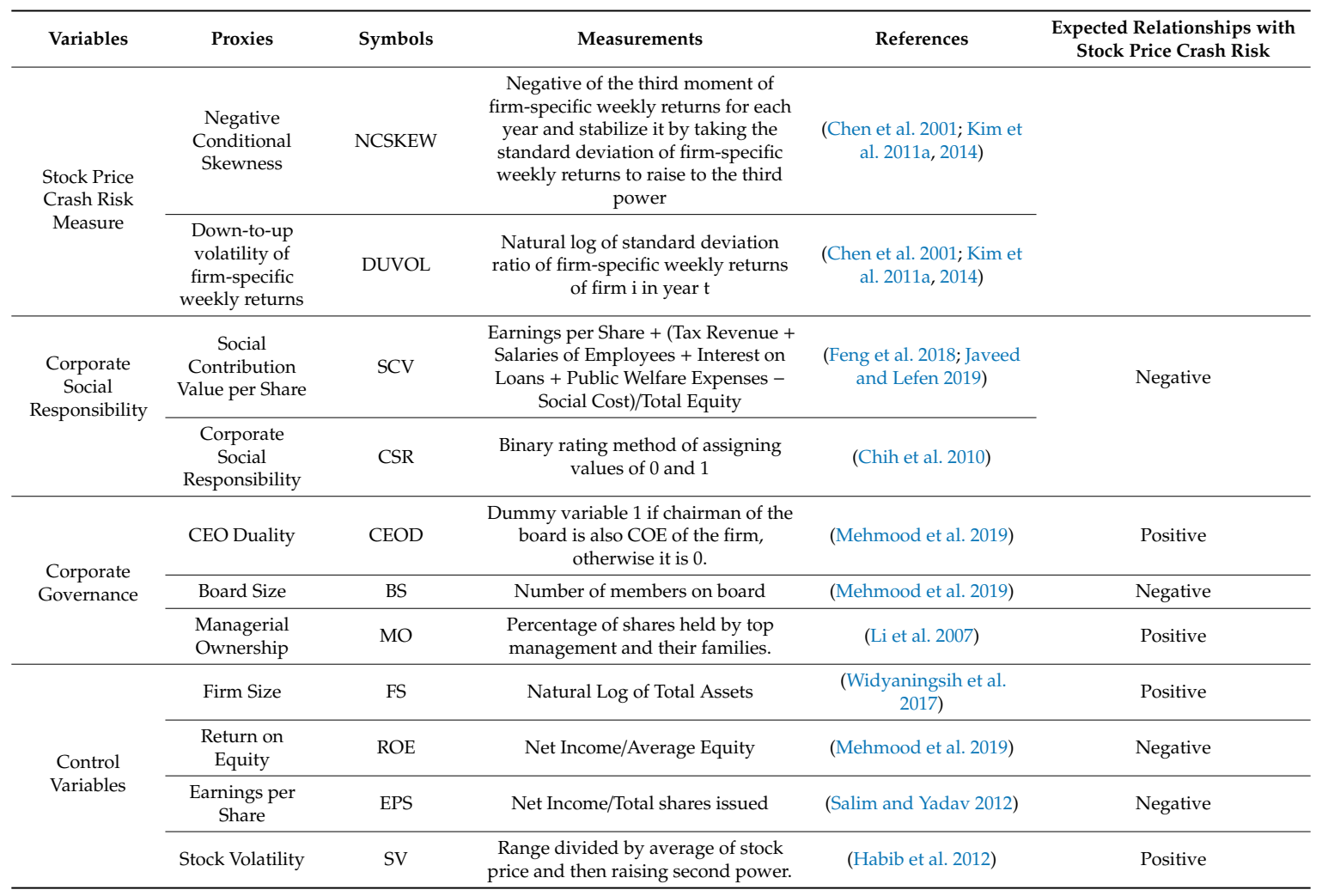

We use the following equations to analyze the data.

$$
\begin{aligned}
& (\mathrm{NCSKEW})_{\mathrm{i}, \mathrm{t}}=\alpha+\beta_{1}(\mathrm{SCV})_{\mathrm{i}, \mathrm{t}}+\beta_{2}(\mathrm{CSR})_{\mathrm{i}, \mathrm{t}}+\beta_{3}(\mathrm{CGI})_{\mathrm{i}, \mathrm{t}}+\beta_{4}(\mathrm{FS})_{i, \mathrm{t}}+\beta_{5}(\mathrm{ROE})_{\mathrm{i}, \mathrm{t}}+\beta_{6}(\mathrm{EPS})_{\mathrm{i}, \mathrm{t}}+\beta_{7}(\mathrm{SV})_{\mathrm{i}, \mathrm{t}}+\mu_{\mathrm{i}, \mathrm{t}} \\
& (\mathrm{DUVOL})_{\mathrm{i}, \mathrm{t}}=\alpha+\beta_{1}(\mathrm{SCV})_{\mathrm{i}, \mathrm{t}}+\beta_{2}(\mathrm{CSR})_{\mathrm{i}, \mathrm{t}}+\beta_{3}(\mathrm{CGI})_{\mathrm{i}, \mathrm{t}}+\beta_{4}(\mathrm{FS})_{\mathrm{i}, \mathrm{t}}+\beta_{5}(\mathrm{ROE})_{\mathrm{i}, \mathrm{t}}+\beta_{6}(\mathrm{EPS})_{\mathrm{i}, \mathrm{t}}+\beta_{7}(\mathrm{SV})_{\mathrm{i}, \mathrm{t}}+\mu_{\mathrm{i}, \mathrm{t}}
\end{aligned}
$$

\section{Results and Hypotheses Testing}

We explain the descriptive statistics and correlation analysis in Table 2. We find a small value of negative conditional skewness, which means that on average, firms have low negative returns. The average values of CSV and CSR show that firms in India and Pakistan are keen to engage themselves in social activities. This further implies that firms in this region are still at a growing stage in contributing to improving the environment and society. Outcomes regarding corporate governance indicate that firms are serious about governance mechanisms. Firms do not prefer the chairman of the board to act as CEO. On average, seven members work on a board, which is a reasonable number as per the requirement of the governance system. Results also indicate that firms prefer to issue shares to top management; executives, managers, directors and their family members. There is more variation in firm size and less consistency in an investment of total assets. It further explains that firms spend money on total assets depending on the need and availability of financial sources. 
Table 2. Descriptive statistics and correlation analysis (overall).

\begin{tabular}{|c|c|c|c|c|c|c|c|c|c|c|c|c|c|}
\hline & Mean & S.D. & NCSKEW & DUVOL & SCV & CSR & CEOD & BS & MO & FS & ROE & EPS & SV \\
\hline NCSKEW & -0.016 & 1.137 & 1.000 & & & & & & & & & & \\
\hline DUVOL & -0.110 & 0.435 & 0.071 & 1.000 & & & & & & & & & \\
\hline SCV & 0.054 & 0.061 & 0.142 & 0.215 & 1.000 & & & & & & & & \\
\hline CSR & 0.873 & 0.334 & 0.084 & 0.094 & 0.551 & 1.000 & & & & & & & \\
\hline CEOD & 0.120 & 0.326 & 0.016 & 0.011 & 0.072 & 0.037 & 1.000 & & & & & & \\
\hline BS & 7.234 & 1.550 & 0.045 & 0.065 & 0.413 & 0.287 & -0.011 & 1.000 & & & & & \\
\hline MO & 37.238 & 24.848 & 0.059 & 0.079 & -0.073 & -0.059 & 0.072 & -0.243 & 1.000 & & & & \\
\hline FS & 17.918 & 7.225 & -0.084 & -0.093 & -0.218 & -0.148 & -0.346 & -0.277 & 0.091 & 1.000 & & & \\
\hline ROE & 0.241 & 0.466 & 0.007 & 0.012 & 0.099 & 0.074 & 0.078 & -0.015 & -0.057 & -0.065 & 1.000 & & \\
\hline EPS & 33.799 & 60.560 & 0.026 & 0.031 & 0.189 & 0.153 & 0.094 & 0.006 & -0.016 & -0.035 & 0.493 & 1.000 & \\
\hline SV & 0.067 & 0.088 & -0.095 & -0.088 & -0.231 & -0.123 & 0.103 & -0.051 & -0.042 & -0.031 & -0.049 & -0.096 & 1.000 \\
\hline
\end{tabular}

Note: NCSKEW = Negative Conditional Skewness, DUVOL = Down-to-up volatility, S.D. = Standard Deviation, SCV = Social Contribution Value per Share, CSR = Corporate

Social Responsibility, CEOD = Chief Executive Officer Duality, BS = Board Size, MO = Managerial Ownership, FS = Firm Size, ROE = Return on Equity, EPS = Earnings per Share, $\mathrm{SV}=$ Stock Volatility. 
On average, firms earn a high return on equity with less variation in the values. Earnings per share of the firms is high with a large variation in the value, which shows inconsistency in earnings per share of the firms. We find less variation in the values of stock price volatility, and average volatility in stock prices is also low. It shows that firms keep a balance of stock prices to meet the challenges of unstable economic conditions. Table 2 further explains the correlation analysis among independent and control variables. We find that there is a weak correlation among variables, which proves no multicollinearity problem exists in the model.

We present the Variance Inflation Factor (VIF) test in Table 3 to verify the multicollinearity, which may occur due to the overlapping of variables. VIF values show that there is no multicollinearity problem.

Table 3. Test for multicollinearity.

\begin{tabular}{ccc}
\hline Variable & VIF & 1/VIF \\
\hline EPS & 1.360 & 0.735 \\
ROE & 1.330 & 0.750 \\
FS & 1.260 & 0.793 \\
BS & 1.240 & 0.807 \\
CEOD & 1.180 & 0.844 \\
CSR & 1.140 & 0.881 \\
SCV & 1.462 & 0.696 \\
MO & 1.080 & 0.925 \\
SV & 1.040 & 0.961 \\
\hline
\end{tabular}

Note: VIF = Variance Inflation Factor.

Table 4 illustrates the results of GMM for the overall manufacturing sector of Pakistan and India. We find that SCV and CSR negatively impact the stock price crash risk of firms. This signifies that when firms are more active in their CSR activities and contribute towards society, they also contribute to reduced stock price crash risk.

Further, outcomes of corporate governance reveal that the dual responsibilities of CEO and board size show significant and inverse influences on stock price crash risk. However, managerial ownership shows a positive and significant impact on both measures of stock price crash risk. The results of managerial ownership show that managers are likely to operate for their own interests, which ultimately affects stock price crash risk positively. Results of the control variables of our study are generally consistent with past studies. Analysis indicates that firm size has a significant and positive influence on stock price crash risk, which follows the outcomes of (Chen et al. 2001; Kim et al. 2014). Findings of stock volatility also indicate a high crash risk which is in line with the outcomes of (Kim et al. 2014). However, outcomes also confirm that there is low crash risk with an increase in earnings per share. In addition, return on equity does not show any significant outcome on crash risk.

We explain country-wise findings in Table 5 to confirm the robustness of our findings. We find that CSV and CSR show a significant and inverse relationship with stock price crash risk in both countries. Further, we conclude that CSR firms have less chance of risk associated with stock price crashes for emerging economies of Pakistan and India. Results also indicate that board members and CEO duality reveal significant inverse effects on stock price crash risk in both countries. However, the impact is positive only in the case of managerial ownership. In particular, when the financial performance of a firm goes down more than investors expect, managers try to hide the bad news to safeguard their reputation, wealth, and jobs (Gormley et al. 2013). Findings of control variables suggest that firm size and sock volatility positively impact the stock price crash risk. Earning per share shows a significant and negative influence on crash risk. However, findings show varying outcomes with respect to the impact of return on equity on stock price crash risk for different models. 
Table 4. The two-step system dynamic panel regression (overall).

\begin{tabular}{|c|c|c|c|c|c|c|}
\hline & \multicolumn{3}{|c|}{ Dependent Variable: NCSKEW } & \multicolumn{3}{|c|}{ Dependent Variable: DUVOL } \\
\hline & Model 1 & Model 2 & Model 3 & Model 1 & Model 2 & Model 3 \\
\hline L1. & $\begin{array}{c}-0.009 \\
(-0.230)\end{array}$ & $\begin{array}{c}0.126^{* * *} \\
(2.800)\end{array}$ & $\begin{array}{l}0.036^{* *} \\
(1.971)\end{array}$ & $\begin{array}{c}1.079 * * * \\
(5.691)\end{array}$ & $\begin{array}{c}0.063 \\
(1.251)\end{array}$ & $\begin{array}{c}0.0371^{* * * *} \\
(3.412)\end{array}$ \\
\hline $\mathrm{L} 2$. & $\begin{array}{c}-0.074 * * \\
(-2.030)\end{array}$ & $-0.041-0.820$ & $\begin{array}{c}-0.076^{* * *} \\
(-3.072)\end{array}$ & $\begin{array}{c}0.520 \\
(1.591)\end{array}$ & $\begin{array}{l}0.279 \\
(1.06)\end{array}$ & $\begin{array}{c}0.307^{* * *} \\
(3.233) \\
\end{array}$ \\
\hline SCV & $\begin{array}{c}-1.913 * * * \\
(-2.710)\end{array}$ & - & $\begin{array}{l}-1.977^{* *} \\
(-2.447)\end{array}$ & $\begin{array}{l}-0.015^{* * *} \\
(-13.381)\end{array}$ & - & $\begin{array}{c}-0.337^{* * * *} \\
(-3.151)\end{array}$ \\
\hline CSR & - & $\begin{array}{l}-0.254^{* *} \\
(-2.311)\end{array}$ & $\begin{array}{l}-0.002 * \\
(-1.787)\end{array}$ & - & $\begin{array}{l}-0.031 * \\
(-1.720)\end{array}$ & $\begin{array}{l}-0.209 * * \\
(-1.989)\end{array}$ \\
\hline CEOD & $\begin{array}{c}-0.083 * * * * \\
(-2.970)\end{array}$ & $\begin{array}{l}-0.950 * \\
(-1.711)\end{array}$ & $\begin{array}{c}-0.049^{* * *} \\
(14.657)\end{array}$ & $\begin{array}{c}-0.067^{* * *} \\
(-8.198)\end{array}$ & $\begin{array}{l}-0.897^{*} \\
(-1.723)\end{array}$ & $\begin{array}{l}-1.240 * * \\
(-2.793)\end{array}$ \\
\hline BS & $\begin{array}{l}-0.145^{*} \\
(-1.710)\end{array}$ & $\begin{array}{l}-1.832 * \\
(-1.841)\end{array}$ & $\begin{array}{c}-0.061 \text { *** } \\
(-2.941)\end{array}$ & $\begin{array}{l}-0.011 * \\
(-1.823)\end{array}$ & $\begin{array}{c}0.001 \\
(0.224)\end{array}$ & $\begin{array}{c}-0.017^{* * *} \\
(-4.132)\end{array}$ \\
\hline $\mathrm{MO}$ & $\begin{array}{l}0.006^{*} \\
(1.810)\end{array}$ & $\begin{array}{c}1.015 \\
(0.721)\end{array}$ & $\begin{array}{c}0.357^{* * *} \\
(2.731)\end{array}$ & $\begin{array}{l}0.005^{*} \\
(2.261)\end{array}$ & $\begin{array}{l}0.007^{* * *} \\
(18.812)\end{array}$ & $\begin{array}{l}0.006^{*} \\
(1.891)\end{array}$ \\
\hline FS & $\begin{array}{l}0.422 * \\
(1.610)\end{array}$ & $\begin{array}{l}0.512 * * \\
(1.991)\end{array}$ & $\begin{array}{c}0.031 * * * \\
(2.845)\end{array}$ & $\begin{array}{c}0.005 \\
(0.623)\end{array}$ & $\begin{array}{c}0.467^{* * *} \\
(3.361)\end{array}$ & $\begin{array}{c}0.004^{* * *} \\
(4.191)\end{array}$ \\
\hline $\mathrm{ROE}$ & $\begin{array}{c}-0.031 \\
(-0.580)\end{array}$ & $\begin{array}{c}-0.004 \\
(-0.612)\end{array}$ & $\begin{array}{c}-0.021 \\
(-0.071)\end{array}$ & $\begin{array}{c}0.001 \\
(0.631)\end{array}$ & $\begin{array}{l}-0.005^{*} \\
(-1.681)\end{array}$ & $\begin{array}{c}-0.003 \\
(-0.762)\end{array}$ \\
\hline EPS & $\begin{array}{l}-0.049 * * \\
(-1.950)\end{array}$ & $\begin{array}{l}-0.084^{* *} \\
(-2.244)\end{array}$ & $\begin{array}{c}-0.561^{* * *} \\
(-3.342)\end{array}$ & $\begin{array}{c}-0.001 \\
(-0.343)\end{array}$ & $\begin{array}{c}-0.002 \\
(-0.162)\end{array}$ & $\begin{array}{c}-0.129 * * * \\
(-9.011)\end{array}$ \\
\hline SV & $\begin{array}{l}0.126^{* *} \\
(2.400)\end{array}$ & $\begin{array}{c}0.027 \\
(0.938)\end{array}$ & $\begin{array}{l}0.003 * \\
(1.941)\end{array}$ & $\begin{array}{l}0.687^{*} \\
(1.731)\end{array}$ & $\begin{array}{l}0.113^{*} \\
(1.876)\end{array}$ & $\begin{array}{c}0.161 * * * \\
(9.217)\end{array}$ \\
\hline $\mathrm{C}$ & $\begin{array}{l}2.050 * * \\
(2.380)\end{array}$ & $\begin{array}{l}1.512 \text { ** } \\
(2.110)\end{array}$ & $\begin{array}{c}0.449 * * * \\
(8.322)\end{array}$ & $\begin{array}{c}2.295 \\
(0.623)\end{array}$ & $\begin{array}{c}0.012 \\
(0.501)\end{array}$ & $\begin{array}{l}0.181^{* *} \\
(2.632)\end{array}$ \\
\hline
\end{tabular}

Note: Model 1 represents SCV as the first measure of CSR; model 2 represents the second measure of CSR, whereas model 3 shows the overall analysis including both measures of CSR. L1 = First lag of dependent variable, L2 = Second lag of dependent variable, NCSKEW = Negative Conditional Skewness, DUVOL = Down-to-up volatility, SCV = Social Contribution Value per Share, CSR = Corporate Social Responsibility, CEOD = Chief Executive Officer Duality, BS = Board Size, MO = Managerial Ownership, FS = Firm Size, ROE = Return on Equity, EPS $=$ Earnings per Share, SV $=$ Stock Volatility, $C=$ Constant, ${ }^{* * *},{ }^{* *}$, and ${ }^{*}$ represents significant level at $1 \%, 5 \%$, and $10 \%$. 
Table 5. Two-step dynamic panel estimation (country-wise).

\begin{tabular}{|c|c|c|c|c|c|c|c|c|c|c|c|c|}
\hline & \multicolumn{6}{|c|}{ Pakistan } & \multicolumn{6}{|c|}{ India } \\
\hline & \multicolumn{3}{|c|}{ NCSKEW } & \multicolumn{3}{|c|}{ DUVOL } & \multicolumn{3}{|c|}{ NCSKEW } & \multicolumn{3}{|c|}{ DUVOL } \\
\hline & Model 1 & Model 2 & Model 3 & Model 1 & Model 2 & Model 3 & Model 1 & Model 2 & Model 3 & Model 1 & Model 2 & Model 3 \\
\hline L1. & $\begin{array}{c}0.129 * * * \\
(3.120)\end{array}$ & $\begin{array}{l}0.297^{* * *} \\
(10.345)\end{array}$ & $\begin{array}{c}0.176^{* * *} \\
(6.927)\end{array}$ & $\begin{array}{c}0.129^{* * *} \\
(8.441)\end{array}$ & $\begin{array}{c}0.018 \\
(0.637)\end{array}$ & $\begin{array}{c}0.710^{* * *} \\
(9.589)\end{array}$ & $\begin{array}{l}0.057 * * \\
(2.373)\end{array}$ & $\begin{array}{c}0.382 * * * \\
(6.422)\end{array}$ & $\begin{array}{c}2.398 \\
(1.076)\end{array}$ & $\begin{array}{c}-0.016 \\
(-0.430)\end{array}$ & $\begin{array}{c}0.133^{* * *} \\
(3.927)\end{array}$ & $\begin{array}{l}0.187^{*} \\
(1.968)\end{array}$ \\
\hline L2. & $\begin{array}{c}-0.052 \\
(-1.170)\end{array}$ & $\begin{array}{c}-0.136^{* * *} \\
(-2.831)\end{array}$ & $\begin{array}{l}-0.048^{* * *} \\
(-13.049)\end{array}$ & $\begin{array}{c}0.002 \\
(1.392) \\
\end{array}$ & $\begin{array}{c}0.023 \\
(0.117) \\
\end{array}$ & $\begin{array}{l}0.346^{* * *} \\
(10.046)\end{array}$ & $\begin{array}{c}2.234 \\
(1.013) \\
\end{array}$ & $\begin{array}{c}0.637^{* * *} \\
(7.956)\end{array}$ & $\begin{array}{c}0.301^{* * *} \\
(6.861)\end{array}$ & $\begin{array}{c}0.003 \\
(0.060) \\
\end{array}$ & $\begin{array}{c}0.071 * * * \\
(4.281)\end{array}$ & $\begin{array}{c}-0.019 \text { **** } \\
(-2.789)\end{array}$ \\
\hline SCV & $\begin{array}{c}-0.128^{* * *} \\
(-2.840)\end{array}$ & - & $\begin{array}{c}-0.185^{* * *} \\
(-3.307)\end{array}$ & $\begin{array}{c}-0.161^{* * *} \\
(-8.120)\end{array}$ & - & $\begin{array}{c}-0.261 * * * \\
(-3.619)\end{array}$ & $\begin{array}{l}-0.18^{* * *} \\
(-7.967)\end{array}$ & - & $\begin{array}{c}-0.127^{* * *} \\
(-3.671)\end{array}$ & $\begin{array}{l}-0.025^{* *} \\
(-2.163)\end{array}$ & - & $\begin{array}{l}-0.649 * \\
(-1.889)\end{array}$ \\
\hline CSR & - & $\begin{array}{c}-0.170^{* * *} \\
(-7.118)\end{array}$ & $\begin{array}{l}-0.390 * \\
(-1.670)\end{array}$ & - & $\begin{array}{c}-0.097^{* * *} \\
(-3.135)\end{array}$ & $\begin{array}{c}-0.305^{* * *} \\
(-2.395)\end{array}$ & - & $\begin{array}{c}-0.016 \\
(-1.249)\end{array}$ & $\begin{array}{l}-0.446 * \\
(-1.656)\end{array}$ & - & $\begin{array}{l}-0.171^{* * *} \\
(-12.095)\end{array}$ & $\begin{array}{l}-0.017^{* *} \\
(-2.435)\end{array}$ \\
\hline CEOD & $\begin{array}{l}0.692 * \\
(1.950)\end{array}$ & $\begin{array}{c}0.055^{* * *} \\
(2.881)\end{array}$ & $\begin{array}{c}-0.089^{* * *} \\
(-3.171)\end{array}$ & $\begin{array}{c}-0.043 \\
(-1.054)\end{array}$ & $\begin{array}{c}-0.176^{* * *} \\
(-7.929)\end{array}$ & $\begin{array}{l}-0.315^{*} \\
(-2.495)\end{array}$ & $\begin{array}{l}-0.650 * \\
(-1.887)\end{array}$ & $\begin{array}{c}-0.024 \\
(-1.187)\end{array}$ & $\begin{array}{c}-0.478^{* * *} \\
(-3.329)\end{array}$ & $\begin{array}{c}-1.653 * * * \\
(-2.780)\end{array}$ & $\begin{array}{c}-0.036^{* * *} \\
(-16.882)\end{array}$ & $\begin{array}{l}-0.035^{* *} \\
(-18.231)\end{array}$ \\
\hline BS & $\begin{array}{c}-0.126^{* * *} \\
(-3.890)\end{array}$ & $\begin{array}{l}-0.115^{*} \\
(-1.711)\end{array}$ & $\begin{array}{l}-0.249^{* * *} \\
(-34.465)\end{array}$ & $\begin{array}{c}-0.019^{* * *} \\
(-2.801)\end{array}$ & $\begin{array}{c}0.015 \\
(0.529)\end{array}$ & $\begin{array}{l}-0.239 * \\
(-1.899)\end{array}$ & $\begin{array}{c}-0.067 \\
(-1.315)\end{array}$ & $\begin{array}{l}-0.536^{*} \\
(-1.735)\end{array}$ & $\begin{array}{l}-0.559 * \\
(-1.819)\end{array}$ & $\begin{array}{l}-1.120^{* *} \\
(-2.160)\end{array}$ & $\begin{array}{c}-0.292 * * \\
(-2.110)\end{array}$ & $\begin{array}{c}-0.351^{* * *} \\
(-10.341)\end{array}$ \\
\hline $\mathrm{MO}$ & $\begin{array}{l}0.006 * \\
(1.910)\end{array}$ & $\begin{array}{l}0.002 * \\
(1.773\end{array}$ & $\begin{array}{c}0.017^{* *} \\
(2.553)\end{array}$ & $\begin{array}{c}0.018^{* *} \\
(2.510)\end{array}$ & $\begin{array}{c}0.275 \\
(0.149)\end{array}$ & $\begin{array}{c}0.487 \\
(1.586)\end{array}$ & $\begin{array}{c}0.068^{* * *} \\
(2.918)\end{array}$ & $\begin{array}{c}0.002 \\
(1.261) \\
\end{array}$ & $\begin{array}{c}0.051^{* * *} \\
(2.310)\end{array}$ & $\begin{array}{l}0.007^{*} \\
(1.930)\end{array}$ & $\begin{array}{l}0.002 * \\
(1.951)\end{array}$ & $\begin{array}{l}0.001 * \\
(1.771) \\
\end{array}$ \\
\hline FS & $\begin{array}{l}0.015^{* *} \\
(2.412)\end{array}$ & $\begin{array}{c}0.071 \\
(0.115)\end{array}$ & $\begin{array}{l}0.004^{* *} \\
(2.117)\end{array}$ & $\begin{array}{c}0.187 \\
(0.160)\end{array}$ & $\begin{array}{l}0.549 * \\
(1.698) \\
\end{array}$ & $\begin{array}{l}-0.002 * \\
(-1.667)\end{array}$ & $\begin{array}{l}0.031 \text { * } \\
(1.690)\end{array}$ & $\begin{array}{l}0.931 * \\
(1.817) \\
\end{array}$ & $\begin{array}{l}0.132 * \\
(1.681) \\
\end{array}$ & $\begin{array}{c}0.015 \\
(0.531)\end{array}$ & $\begin{array}{c}0.545^{* * *} \\
(3.200)\end{array}$ & $\begin{array}{l}0.724^{* *} \\
(2.137)\end{array}$ \\
\hline ROE & $\begin{array}{c}-0.068 \\
(-0.390)\end{array}$ & $\begin{array}{c}-0.019 \\
(-0.734)\end{array}$ & $\begin{array}{c}-0.023 \\
(-0.819)\end{array}$ & $\begin{array}{c}0.478^{* * *} \\
(7.677)\end{array}$ & $\begin{array}{c}0.020 \\
(0.725) \\
\end{array}$ & $\begin{array}{l}0.007^{*} \\
(2.425) \\
\end{array}$ & $\begin{array}{c}0.005 \\
(1.231) \\
\end{array}$ & $\begin{array}{c}0.143 \\
(1.521) \\
\end{array}$ & $\begin{array}{c}0.139 \\
(1.497) \\
\end{array}$ & $\begin{array}{c}0.064^{* * *} \\
(2.930)\end{array}$ & $\begin{array}{c}0.054 \\
(1.612) \\
\end{array}$ & $\begin{array}{l}0.032 * \\
(2.207) \\
\end{array}$ \\
\hline EPS & $\begin{array}{l}-0.102 * \\
(-1.730) \\
\end{array}$ & $\begin{array}{c}-0.794^{* * *} \\
(-4.271)\end{array}$ & $\begin{array}{l}-0.604 * \\
(-1.834) \\
\end{array}$ & $\begin{array}{l}-0.061 * \\
(-1.822) \\
\end{array}$ & $\begin{array}{c}0.295 \\
(1.269) \\
\end{array}$ & $\begin{array}{c}-0.057 * * \\
(-2.539) \\
\end{array}$ & $\begin{array}{c}-0.081 \\
(-1.321) \\
\end{array}$ & $\begin{array}{l}-0.059 * \\
(-1.691) \\
\end{array}$ & $\begin{array}{c}-0.369 * * \\
(-1.911)\end{array}$ & $\begin{array}{c}-0.017 \text { ** } \\
(-2.150)\end{array}$ & $\begin{array}{c}-0.001 \\
(-1.169) \\
\end{array}$ & $\begin{array}{c}-0.189 * * \\
(-2.401)\end{array}$ \\
\hline SV & $\begin{array}{l}1.954^{*} \\
(1.880)\end{array}$ & $\begin{array}{l}0.184^{* *} \\
(2.230)\end{array}$ & $\begin{array}{l}0.397^{*} \\
(1.720)\end{array}$ & $\begin{array}{c}0.184 \\
(0.129)\end{array}$ & $\begin{array}{l}0.386^{*} \\
(1.691)\end{array}$ & $\begin{array}{c}0.079 * * * \\
(3.431)\end{array}$ & $\begin{array}{l}0.749 * \\
(1.689)\end{array}$ & $\begin{array}{c}0.137 \\
(1.489)\end{array}$ & $\begin{array}{l}0.129 * \\
(1.812)\end{array}$ & $\begin{array}{c}0.079 \\
(1.129)\end{array}$ & $\begin{array}{c}0.471^{* * *} \\
(2.960)\end{array}$ & $\begin{array}{l}0.277^{*} \\
(1.743)\end{array}$ \\
\hline C & $\begin{array}{c}1.448 \\
(0.940)\end{array}$ & $\begin{array}{c}0.639 \\
(0.772)\end{array}$ & $\begin{array}{l}0.056^{*} \\
(1.685)\end{array}$ & $\begin{array}{l}0.041 \text { * } \\
(3.178)\end{array}$ & $\begin{array}{l}0.059 * \\
(2.170)\end{array}$ & $\begin{array}{l}0.025 * * \\
(2.165)\end{array}$ & $\begin{array}{c}0.114 \\
(1.311)\end{array}$ & $\begin{array}{l}0.052 * \\
(1.757)\end{array}$ & $\begin{array}{l}0.056^{*} \\
(1.893)\end{array}$ & $\begin{array}{c}2.817 \\
(0.640)\end{array}$ & $\begin{array}{c}0.017 \\
(0.483)\end{array}$ & $\begin{array}{l}0.066^{* *} \\
(1.877)\end{array}$ \\
\hline
\end{tabular}




\section{Discussion}

Our results show that CSR and corporate governance are important determinants of crash risk for manufacturing firms in emerging economies (Pakistan and India). The negative impacts of both measures of CSR on crash risk demonstrate that with increased corporate social responsibilities activities, the chances of crash risk are reduced. Thus, we conclude that firms with CSR have less chance of risk associated with stock price crashes for emerging economies. In line with the findings of (Kim et al. 2014; Lee 2016), this study entails that firms with CSR have more transparent financial reporting standards that lead to a low level of crash risk.

The positive impact of managerial ownership on stock price crash risk reveals robust evidence that managerial ownership is a reliable tool to predict future risk of the stock price (Huang et al. 2017). Further, managerial ownership creates agency problems where owners prefer their personal benefits over firms' benefits. In addition, managerial ownership also leads managers to hide bad news, which also increases stock price crash risk. The findings of managerial ownership are similar to the outcomes of (Andreou et al. 2016). Findings of CEO duality justify organizational and management theory, which explains that when a CEO has high power, he/she has more advantages, which results in less costly outcomes (Sah and Stiglitz 1986). Integrated leadership helps to alleviate costs relating to information acquisition and coordination, and it also enables adaptability and better decision making (Boyd 1995; Jensen and Heckling 1995; Li et al. 2019). In addition, (Adams and Ferreira 2007) explain that when CEOs have more power, they are keen to share more inside information with boards with unified leadership, which is useful for firms. This implies that CEOs who are at the same time chairmen of boards may try to avoid shareholder monitoring by disclosing information as a bonding behavior. Further, findings indicate that directors on boards play a major part in corporate governance, mainly in monitoring top-level management (Fama and Jensen 1983). The monitoring of the board of directors plays a role to decrease stock price crash risk. This further indicates that corporate governance plays a monitoring role that mitigates the opportunistic behavior of the managers which negatively affects stock price crash risk, and our results are aligned with the findings of (An and Zhang 2013).

The negative impact of board size signifies that when there is age diversity in board size that includes both young and old directors, it helps to reduce stock crash risk (Jebran et al. 2020). In addition, (Andreou et al. 2017) find that young CEOs' positively influence stock crash risk as they have the motivation to possess negative information during the starting period of their career.

\section{Conclusions}

We analyze the effects of CSR and corporate governance on stock price crash risk in Pakistan and India. We select 353 firms from the manufacturing sector of both countries. We find that CSR, CEO duality and board size negatively impact the stock price crash risk of the firms operating in emerging economies (Pakistan and India). This implies that CSR and corporate governance are means to lower the crash risk. However, our findings show that managerial ownership has a positive relationship with stock price crash risk. The outcome of managerial ownership confirms agency issues prevailing in firms where management prefers their own interest instead of shareholders' interest, which leads to enhanced crash risk. Managers of firms can find benefits from our study in order to improve corporate strategies and policies by adopting effective corporate governance mechanisms. As emerging countries (Pakistan and India) are facing unstable economic conditions, the findings of our study provide insight for the management of firms and for investors to emphasize social contribution in order to reduce stock price crash risk and stabilize capital markets. Our study is beneficial for firms because an effective governance system helps to lower crash risk. Therefore, it is in the primary interest of shareholders to invest their funds in those firms that have better corporate governance practices. Outcomes of our study imply that managerial ownership contributes to implementing effective policies relating to risk management. Further, findings suggest that corporate governance practices lead to mitigate opportunistic performance of management; they also help to reduce stock price crash risk. This further shows that a decrease in crash risk indicates high efficiency of corporate governance practices. 
The findings of our study encourage managers and owners to contribute more in CSR practices. Our study may provide a guide for investors to select firms with high CSR practices while investing funds to cover the loss caused by stock price crashes to their personal interests. Therefore, our study is helpful for investors who involve themselves in managing their crash risk while investing in stock markets. Our study suggests investors should consider necessary information about CSR practices as a factor influencing the stock price crash risks of the firms. Policymakers may focus more on implementing efficient corporate governance and CSR practices to attract investors to make their investment more secure. Our study further suggests that if management reacts positively to the demands of firms' stakeholders and focuses on enhancing the relationships with fund providers, customers, and suppliers, then CSR practices not only help to improve the brand image of the firm, but also decrease stock price crash risk. This study is limited to only two countries which can be extended by including more emerging countries and could be used to make a comparative analysis with developed countries. Future research can be done to find some more factors affecting the firm's risk relating to a stock price crash in order to enhance its understanding.

Author Contributions: A.I.H. worked on conceptualization, writing-original draft preparation, writing-review and editing, supervision, R.M. contributes in resources, data curation and formal analysis, whereas T.T. handles the methodology, software and formal Analysis. All authors have read and agreed to the published version of the manuscript.

Funding: This research received no external funding.

Conflicts of Interest: The authors declare no conflict of interest.

\section{References}

Adams, Renée B., and Daniel Ferreira. 2007. A theory of friendly boards. The Journal of Finance 62: 217-50. [CrossRef]

Ali, Waris, and Jedrzej George Frynas. 2018. The role of normative CSR-promoting institutions in stimulating CSR disclosures in developing countries. Corporate Social Responsibility and Environmental Management 25: 373-90. [CrossRef]

Alkurdi, Amneh, Khaled Hussainey, Yasean Tahat, and Mohammad Aladwan. 2019. The impact of corporate governance on risk disclosure: Jordanian evidence. Academy of Accounting and Financial Studies Journal 23: $1-16$.

An, Heng, and Ting Zhang. 2013. Stock price synchronicity, crash risk, and institutional investors. Journal of Corporate Finance 21: 1-15. [CrossRef]

Andreou, Panayiotis C., Constantinos Antoniou, Joanne Horton, and Christodoulos Louca. 2016. Corporate governance and firm-specific stock price crashes. European Financial Management 22: 916-56. [CrossRef]

Andreou, Panayiotis C., Christodoulos Louca, and Andreas P. Petrou. 2017. CEO age and stock price crash risk. Review of Finance 21: 1287-325. [CrossRef]

Arellano, Manuel, and Stephen Bond. 1991. Some tests of specification for panel data: Monte Carlo evidence and an application to employment equations. The Review of Economic Studies 58: 277-97. [CrossRef]

Arellano, Manuel, and Olympia Bover. 1995. Another look at the instrumental variable estimation of error-components models. Journal of Econometrics 68: 29-51. [CrossRef]

Ayadi, Wafa Masmoudi, and Younes Boujelbène. 2015. Internal governance mechanisms and value relevance of accounting earnings: An empirical study in the French context. International Journal of Managerial and Financial Accounting 7: 3-25. [CrossRef]

Bedard, Jean C., and Karla M. Johnstone. 2004. Earnings manipulation risk, corporate governance risk, and auditors' planning and pricing decisions. The Accounting Review 79: 277-304. [CrossRef]

Bhagat, Sanjai, and Brian Bolton. 2008. Corporate governance and firm performance. Journal of Corporate Finance 14: 257-73. [CrossRef]

Bhasin, Madan Lal, and Junaid M. Shaikh. 2013. Voluntary corporate governance disclosures in the annual reports: An empirical study. International Journal of Managerial and Financial Accounting 5: 79-105. [CrossRef]

Boubaker, Sabri, and Duc Khuong Nguyen. 2012. Board Directors and Corporate Social Responsibility. London: Palgrave Macmillan. 
Boubaker, Sabri, and Duc Khuong Nguyen. 2014. Corporate Governance and Corporate Social Responsibility: Emerging Markets Focus. Singapore: World Scientific.

Boubaker, Sabri, Bang Dang Nguyen, and Duc Khuong Nguyen. 2012. Corporate Governance: Recent Developments and New Trends. Berlin: Springer Science \& Business Media.

Boubaker, Sabri, Hatem Mansali, and Hatem Rjiba. 2014. Large controlling shareholders and stock price synchronicity. Journal of Banking \& Finance 40: 80-96.

Boyd, Brian K. 1995. CEO duality and firm performance: A contingency model. Strategic Management Journal 16: 301-12. [CrossRef]

Brennan, Niamh M., and Jill Solomon. 2008. Corporate governance, accountability and mechanisms of accountability: An overview. Accounting, Auditing \& Accountability Journal 21: 885-906.

Callan, Scott J., and Janet M. Thomas. 2014. Relating CEO compensation to social performance and financial performance: Does the measure of compensation matter? Corporate Social Responsibility and Environmental Management 21: 202-27. [CrossRef]

Callen, Jeffrey L., and Xiaohua Fang. 2013. Institutional investor stability and crash risk: Monitoring versus short-termism? Journal of Banking E Finance 37: 3047-63.

Callen, Jeffrey L., and Xiaohua Fang. 2015. Short interest and stock price crash risk. Journal of Banking E Finance 60: 181-94.

Camelia-Daniela Hategan, Nicoleta Sirghi, Ruxandra-Ioana Curea-Pitorac, and Vasile-Petru Hategan. 2018. Doing well or doing good: The relationship between corporate social responsibility and profit in Romanian companies. Sustainability 10: 1041. [CrossRef]

Chang, Xin, Yangyang Chen, and Leon Zolotoy. 2017. Stock liquidity and stock price crash risk. Journal of Financial and Quantitative Analysis 52: 1605-37. [CrossRef]

Chen, Joseph, Harrison Hong, and Jeremy C. Stein. 2001. Forecasting crashes: Trading volume, past returns, and conditional skewness in stock prices. Journal of financial Economics 61: 345-81. [CrossRef]

Chih, Hsiang-Lin, Hsiang-Hsuan Chih, and Tzu-Yin Chen. 2010. On the determinants of corporate social responsibility: International evidence on the financial industry. Journal of Business Ethics 93: 115-35. [CrossRef]

Choi, Jaepil, and Heli Wang. 2009. Stakeholder relations and the persistence of corporate financial performance. Strategic Management Journal 30: 895-907. [CrossRef]

Claessens, Stijn, and B. Burcin Yurtoglu. 2013. Corporate governance in emerging markets: A survey. Emerging Markets Review 15: 1-33. [CrossRef]

Clarkson, Max E. 1995. A stakeholder framework for analyzing and evaluating corporate social performance. Academy of Management Review 20: 92-117. [CrossRef]

Conrad, Jennifer, Robert F. Dittmar, and Eric Ghysels. 2013. Ex ante skewness and expected stock returns. The Journal of Finance 68: 85-124. [CrossRef]

Dai, Jingwen, Chao Lu, and Jipeng Qi. 2019. Corporate social responsibility disclosure and stock price crash risk: Evidence from China. Sustainability 11: 448. [CrossRef]

Darus, Faizah, Hasan Fauzi, Yadi Purwanto, Haslinda Yusoff, Azlan Amran, Mustaffa Mohamed Zain, Dayang Milianna Abang Naim, and Mehran Nejati. 2014. Social responsibility reporting of Islamic banks: Evidence from Indonesia. International Journal of Business Governance and Ethics 9: 356-80. [CrossRef]

Dhaliwal, Dan S., Oliver Zhen Li, Albert Tsang, and Yong George Yang. 2011. Voluntary nonfinancial disclosure and the cost of equity capital: The initiation of corporate social responsibility reporting. The Accounting Review 86: 59-100. [CrossRef]

Donaldson, Lex. 1990. The ethereal hand: Organizational economics and management theory. Academy of Management Review 15: 369-81. [CrossRef]

Donaldson, Lex, and James H. Davis. 1991. Stewardship theory or agency theory: CEO governance and shareholder returns. Australian Journal of Management 16: 49-64. [CrossRef]

Dumitrescu, Dalina, and Liliana Simionescu. 2015. Empirical research regarding the influence of corporate social responsibility (csr) activities on companies' employees and financial performance. Economic Computation $\mathcal{E}$ Economic Cybernetics Studies \& Research 49: 52-66.

El Ghoul, Sadok, Omrane Guedhami, Chuck C. Y. Kwok, and Dev R. Mishra. 2011. Does corporate social responsibility affect the cost of capital? Journal of Banking E Finance 35: 2388-406. 
Fama, Eugene F., and Michael C. Jensen. 1983. Separation of ownership and control. The Journal of Law and Economics 26: 301-25. [CrossRef]

Feng, Ye, Hsing Chen, and Jian Tang. 2018. The impacts of social responsibility and ownership structure on sustainable financial development of China's energy industry. Sustainability 10: 301. [CrossRef]

Gelb, David S., and Joyce A. Strawser. 2001. Corporate social responsibility and financial disclosures: An alternative explanation for increased disclosure. Journal of Business Ethics 33: 1-13. [CrossRef]

González, Víctor M. 2013. Leverage and corporate performance: International evidence. International Review of Economics \& Finance 25: 169-84.

Gormley, Todd A., David A. Matsa, and Todd Milbourn. 2013. CEO compensation and corporate risk: Evidence from a natural experiment. Journal of Accounting and Economics 56: 79-101. [CrossRef]

Goss, Allen, and Gordon S. Roberts. 2011. The impact of corporate social responsibility on the cost of bank loans. Journal of Banking \& Finance 35: 1794-810.

Habib, Yasir, Zernigah Irshad Kiani, and Muhammad Arif Khan. 2012. Dividend policy and share price volatility: Evidence from Pakistan. Global Journal of Management and Business Research 12: 2.

Hao, Dong, Guo Qi, and Jing Wang. 2018. Corporate social responsibility, internal controls, and stock price crash risk: The Chinese stock market. Sustainability 10: 1675. [CrossRef]

Harvey, Campbell R., and Akhtar Siddique. 2000. Conditional skewness in asset pricing tests. The Journal of Finance 55: 1263-95. [CrossRef]

Hillman, Amy J., and Gerald D. Keim. 2001. Shareholder value, stakeholder management, and social issues: What's the bottom line? Strategic Management Journal 22: 125-39. [CrossRef]

Huang, Qinghua, Ye Liu, Fangfang Zhang, and Xiding Chen. 2017. Managerial ownership and stock price crash risk: Evidence from China. Transformations in Business E Economics 16: 688-702.

Hunjra, Ahmed Imran, Uzma Perveen, Leon Li, Muhammad Irfan Chani, and Rashid Mehmood. 2020. Impact of ownership concentration, institutional ownership and earnings management on stock market liquidity. Corporate Ownership \& Control 17: 77-87.

Hutton, Amy P., Alan J. Marcus, and Hassan Tehranian. 2009. Opaque financial reports, R2, and crash risk. Journal of Financial Economics 94: 67-86. [CrossRef]

Istrate, Costel, Ioan-Bogdan Robu, Leontina Pavaloaia, and Ionut Viorel Herghiligiu. 2017. Analysis of companies sustainability under the influence of environmental information disclosure. Environmental Engineering and Management Journal 16: 957-67.

Javeed, Sohail, and Lin Lefen. 2019. An analysis of corporate social responsibility and firm performance with moderating effects of CEO power and ownership structure: A case study of the manufacturing sector of Pakistan. Sustainability 11: 248. [CrossRef]

Jebran, Khalil, Shihua Chen, and Ruibin Zhang. 2020. Board diversity and stock price crash risk. Research in International Business and Finance 51: 101122. [CrossRef]

Jensen, Michael C., and William H. Heckling. 1995. Specific and general knowledge, and organizational structure. Journal of Applied Corporate Finance 8: 4-18. [CrossRef]

Jensen, Michael C., and William H. Meckling. 1976. Theory of the firm: Managerial behavior, agency costs and ownership structure. Journal of Financial Economics 3: 305-60. [CrossRef]

Jiao, Yawen. 2010. Stakeholder welfare and firm value. Journal of Banking $\mathcal{E}$ Finance 34: 2549-61.

Jin, Li, and Stewart C. Myers. 2006. R2 around the world: New theory and new tests. Journal of Financial Economics 79: 257-92. [CrossRef]

Kim, Jeong-Bon, Yinghua Li, and Liandong Zhang. 2011a. Corporate tax avoidance and stock price crash risk: Firm-level analysis. Journal of Financial Economics 100: 639-62. [CrossRef]

Kim, Jeong-Bon, Yinghua Li, and Liandong Zhang. 2011b. CFOs versus CEOs: Equity incentives and crashes. Journal of Financial Economics 101: 713-30. [CrossRef]

Kim, Yongtae, Myung Seok Park, and Benson Wier. 2012. Is earnings quality associated with corporate social responsibility? The Accounting Review 87: 761-96. [CrossRef]

Kim, Yongtae, Haidan Li, and Siqi Li. 2014. Corporate social responsibility and stock price crash risk. Journal of Banking \& Finance 43: 1-13.

Larcker, David F., Scott A. Richardson, and Irem Tuna. 2007. Corporate governance, accounting outcomes, and organizational performance. The Accounting Review 82: 963-1008. [CrossRef] 
Lee, Ming-Te. 2016. Corporate social responsibility and stock price crash risk: Evidence from an Asian emerging market. Managerial Finance 42: 963-79. [CrossRef]

Lemmon, Michael L., and Karl V. Lins. 2003. Ownership structure, corporate governance, and firm value: Evidence from the East Asian financial crisis. The Journal of Finance 58: 1445-68. [CrossRef]

Li, Donghui, Fariborz Moshirian, Pascal Nguyen, and Li-Wen Tan. 2007. Managerial ownership and firm performance: Evidence from China's privatizations. Research in International Business and Finance 21: $396-413$. [CrossRef]

Li, Minwen, Yao Lu, and Gordon M. Phillips. 2019. CEOs and the product market: When are powerful CEOs beneficial? Journal of Financial and Quantitative Analysis 54: 2295-326. [CrossRef]

Mallouh, Alaa Abu, and Asem Tahtamouni. 2018. The impact of social responsibility disclosure on the liquidity of the Jordanian industrial corporations. International Journal of Managerial and Financial Accounting 10: 273-300. [CrossRef]

Mehmood, Rashid, Ahmed Imran Hunjra, and Muhammad Irfan Chani. 2019. The Impact of Corporate Diversification and Financial Structure on Firm Performance: Evidence from South Asian Countries. Journal of Risk and Financial Management 12: 49. [CrossRef]

Mitton, Todd. 2002. A cross-firm analysis of the impact of corporate governance on the East Asian financial crisis. Journal of Financial Economics 64: 215-41. [CrossRef]

Obrad, Ciprian, and Vasile Gherhes. 2018. A Human Resources Perspective on Responsible Corporate Behavior. Case Study: The Multinational Companies in Western Romania. Sustainability 10: 726. [CrossRef]

Pfeffer, Jeffrey. 1972. Merger as a response to organizational interdependence. Administrative Science Quarterly 17: 382-94. [CrossRef]

Pfeffer, Jeffrey, and Gerald R. Salancik. 1978. The External Control of Organizations: A Resource Dependence Perspective. New York: Harper \& Row.

Roman, Ronald M., Sefa Hayibor, and Bradley R. Agle. 1999. The relationship between social and financial performance: Repainting a portrait. Business E Society 38: 109-25.

Rossi, Matteo, Marco Nerino, and Arturo Capasso. 2015. Corporate governance and financial performance of Italian listed firms. The results of an empirical research. Corporate Ownership \& Control 12: 628-43.

Sah, Raaj Kumar, and Joseph E. Stiglitz. 1986. The architecture of economic systems: Hierarchies and polyarchies. The American Economic Review 76: 716-27.

Salim, Mahfuzah, and Raj Yadav. 2012. Capital structure and firm performance: Evidence from Malaysian listed companies. Procedia-Social and Behavioral Sciences 65: 156-66. [CrossRef]

Schuler, Douglas A., and Margaret Cording. 2006. A corporate social performance-corporate financial performance behavioral model for consumers. Academy of Management Review 31: 540-58. [CrossRef]

Shleifer, Andrei, and Robert W. Vishny. 1997. A Survey of Corporate Governance. Journal of Finance 52: 737-83. [CrossRef]

Widyaningsih, Ika Utami, Ardi Gunardi, Matteo Rossi, and Rahmawati Rahmawati. 2017. Expropriation by the controlling shareholders on firm value in the context of Indonesia: Corporate governance as moderating variable. International Journal of Managerial and Financial Accounting 9: 322-37. [CrossRef]

$\mathrm{Xu}$, Nianhang, Xuanyu Jiang, Kam C. Chan, and Zhihong Yi. 2013. Analyst coverage, optimism, and stock price crash risk: Evidence from China. Pacific-Basin Finance Journal 25: 217-39. [CrossRef]

Zhang, Min, Lu Xie, and Haoran Xu. 2016. Corporate philanthropy and stock price crash risk: Evidence from China. Journal of Business Ethics 139: 595-17. [CrossRef]

(C) 2020 by the authors. Licensee MDPI, Basel, Switzerland. This article is an open access article distributed under the terms and conditions of the Creative Commons Attribution (CC BY) license (http://creativecommons.org/licenses/by/4.0/). 